\title{
THE FLOWERING OF HUMAN CONSCIOUSNESS: AN ECOFEMINIST READING OF HAN KANG'S THE VEGETARIAN AND THE FRUIT OF MY WOMAN
}

\section{RINCY CHANDRAN ${ }^{1} \&$ GEETHA R. PAI ${ }^{2}$}

${ }^{I}$ Department of English and Languages School of Arts and Sciences Amrita University Kochi Kerala India

${ }^{2}$ Assistant Professor Department of English and Languages School of Arts and Sciences Amrita University Kochi Kerala India

ABSTRACT
Ecofeminism as a theory is based on the oppression of women and the oppression of nature that are
fundamentally linked. It depicts movements and philosophies that link feminism and ecology. It claims that, if women
understand nature, it is due to their common experience of exploitation. This paper projects, how the concept of
ecofeminism, which was originally postulated in the West, is reflected in Han Kang's The Vegetarian and The Fruit of my
Woman. The aim of the paper is to analyze and interpret the textual and conceptual essence of ecofeminism in the
aforementioned works. To achieve this, it is important to examine the relevant ecofeminist theories and perspectives. The
introduction explores the history and principles of ecofeminism. It investigates man's colonization of nature and woman's
body. Moreover, it discusses the exploitation of woman and nature by considering both as objects. Furthermore, this
paper investigates how the works add a new dimension to ecofeminist discourse. The female characters in these South
Korean works are victims of male domination. The paper shows how women and nature are oppressed by the patriarchy
in the same way and how women and nature, both are showing resistance towards this dominance in their own ways.
KEYWORDS: Ecofeminism, Nature, Woman, Patriarchy \& Domination

Received: Jun 19, 2017; Accepted: Jul 03, 2017; Published: Jul 07, 2017; Paper Id: IJELAUG20173

\section{INTRODUCTION}

Ecofeminism as a theory was developed in the 1970s with the publication of Rachel Carson's The Silent Spring. In Francoise d'Eaubonne's Le féminisme ou la mort, the term 'ecofeminism' first appeared in the year 1974. Women have an affirmative and a close relationship with nature. This is due to the female reproductive role and mothering nature which brings them close to each other. Ecofeminists believe that there is a direct link between the oppression of women and oppression of nature. The nature of women's oppression is interlinked to the nature of oppression of nature. Both are joined at the hip.

Ecofeminism began between the late 1970s and the early 1980s. It was started by academic and professional women. The prefix 'eco' comes from ecology, which is the study of living organisms and their environment. 'Feminism' basically relates to the adequacy for gender equality and women's rights. Using gender as an important point, ecofeminism examines the conditions that cause and perpetuates the subordination of both women and nature. While taking the aspect of exploitation, harmful practices that exploit the environment and social structures that oppress women among other groups have an overlap, and that is what is called ecofeminism.

Ecofeminism comprises of a variety of ideas. It can be credited for such wide ranging concerns. It is used as a feminist and environmental theory. Ecofeminists believe that the largest structure of the society is the system of capitalist patriarchy. Ecofeminism describes using a particular lens of environmental and social problem to get 
feminism in a new light. Some of its central tenants maintain that both types of issues, environmental and social must be addressed together. Women along with the planet are disrespected and deserve respect. An important idea in ecofeminism is the contradiction between matriarchal earth and masculine society.

The focal point of ecofeminism is essentially women and the earth and the relationship they hold. Ecofeminism examines the interaction between women and nature and how both are treated in a male centered society. It is the political and the philosophical concerns that combine ecological and feminist concerns, which results from male domination of society. Rosemary Radford Ruether, Vandana Shiva, Paula Gunn Allen, Andy Smith, Luisah Teish, Ivone Gebara, Alice Walker, Karen Warren, Monica Sjoo and Susan Griffin are among the voices speaking from ecofeminist positions.

Ecofeminism declares that all forms of oppression are connected. All those structures of oppression must be addressed in their totality. Oppression of the nature and of women by patriarchy must be examined together. These oppressions are formed out of the norms created by the power dynamics of patriarchal systems. In one of the ecofeminist books, New Woman, New Earth: Sexist Ideologies and Human Liberation, the author, Rosemary Radford Ruether, states:

Women must see that there can be no liberation for them and no solution to the ecological crisis within a society, whose fundamental model of relationships continues to be one of domination. They must unite the demands of the women's movement with those of the ecological movement to envision a radical reshaping of the basic socioeconomic relations and the underlying values of this society (Ruether, 1975).

Reuther makes a point clear that the earth and women experience the tyranny of patriarchy.

In Paper 11 of the national constitution in 1948, it is discussed about women's suffrage in South Korea. The constitution says, 'All citizens shall be equal before the law and there shall be no discrimination in political, economic, social or cultural life on account of sex, religion or social status.' Still in South Korea, families are ruled by men. Many women are restricted in their job opportunities. The whole society is ruled by patriarchy. There was the emergence of radical feminist groups in South Korea. Women rights organization was divided into two broad categories: those who fight for human rights and those who focus on particular women's rights issues.

Ancient Korea was influenced by ancient Chinese culture. In 1948, South Korea split on its own path away from North Korea. The industrialization, urbanization and westernization of South Korea have changed the lives of the Korean people. South Korea is a carnivore's paradise. The cuisine is based on meats, seafood and rice. Meat dishes such as aspulgogi and kalbi are popular among Koreans. There are no food taboos. Vegetarianism is not encouraged in South Korea. This is because, the majority of people in Korea are meat lovers. Koreans include vegetables in their dishes, but still meat is a very crucial part of Korean cuisine and culture. There are certain situations, where a complete vegan is accepted. One is religion and the other health issues. A meat lover who turns vegan without stating a genuine reason is considered peculiar outsiders.

Han Kang is a South Korean writer. She was born on $27^{\text {th }}$ November, 1970 in Gwangju and at the age of 10 , moved to Seoul. She won the Man Booker Prize for Fiction in 2016 for The Vegetarian. The novel deals with a woman's decision to stop eating meat and its ruinous consequences. It was translated to English by Deborah Smith. The Vegetarian is Kang's first novel to be translated into English. In Kang's college years she became obsessed with a line of poetry from Yi Sang: 'I believe that humans should be plants'. This line of poetry inspired her to resist against the colonial period and to take a defensive stance against the violence in her land and thus led to the successful work, The Vegetarian. 
The Flowering of Human Consciousness: An Ecofeminist Reading of

Han Kang read a lot during her school days. She, later on, revisited those books when she was a teenager. She used to ask questions about being human. Questions like 'What does it mean to be human?', 'Why do people die?', 'Who am I?', 'What is life?' always haunted her. She was surprised that she couldn't find answers to it. She wondered that there were only questions and no answers. She thought that if writing is about asking questions and not necessarily finding answers, she could write that way too. For her, to write is to endlessly question those unanswered questions she had.

The protagonist of The Vegetarian is a woman named Yeong-hye, who sees vegetarianism as a way of not inflicting harm on anything. She believes that eating meat symbolizes human violence, the violence of this world and she chooses vigilant vegetarianism as a way of excluding herself of that violence. But then, she starts to identify her as a plant rather than as a human and stops eating entirely. She becomes completely done in with the ironic result, that what she did to redeem herself ends up killing her.

Han Kang had a story called The Fruit of My Woman about a woman who actually, physically becomes a plant and her husband puts her in a flower pot, waters her and takes care of her. The Vegetarian was a follow-up to this story and she had always been curious about human brutality. This was her motivation to write The Vegetarian. Kang always wanted to explore whether human innocence is possible or not, and what someone would have to overcome to lead a completely blameless life.

Through the novel The Vegetarian, Kang shares the questions, 'Can a person be completely innocent?' and 'What happens when we vow not to hurt anything?' This novel is made up of three parts but ironically the protagonist, Yeonghye, doesn't have a voice. She is a silent character that is observed, desired, misunderstood and pitied. The novel is about two sisters Yeong-hye and In-hye. Yeong-hye is never truly understood by anyone, but In-hye tries to understand and shares her sister's pain.

Yeong-hye doesn't have a voice as a narrator, but she expresses how she feels, through conversation. Yeong-hye says to her sister, 'I was standing on my head... leaves were growing from my body, and roots were sprouting from my hands... so I dug down into the earth. On and on... I wanted flowers to bloom from my crotch so I spread my legs; I spread them wide...' (Kang, 2015). She is recounting how her body is transformed into a plant.

Han Kang was a vegetarian for a few years in her 20s. She has felt the same kind of fear as Yeong-hye. Everyone forced her to eat meat. Later on, she started eating meat again for health reasons, in small amounts. But, she still didn't like meat and always felt a sense of guilt about eating it. Kang knew people who eat meat and who think a lot about the fact that they take other lives to preserve their own. Kang always felt forlorn about the human violence that happened during the Gwangju massacre. On the basis of this bloodbath, she recently published a novel called Here Comes the Boy about a boy who dies during the Gwangju massacre of May 1980. She wrote this novel when she was going through the human violence which has never left her. She wanted to portray this massacre not just as a single incident but as universal. It's not because of the survivor's guilt, but because of Kang's unending question about being human. The Vegetarian was all about questioning innocence, human violence and becoming beings that reject violence. This was what Kang was exploring all her life. Kang's thoughts about vegetarianism and her guilt towards eating meat are connected indirectly to the Gwangju massacre she has experienced. In some ways, Here Comes the Boy and The Vegetarian can be taken as a pair.

Kang's short story collection, The Fruit of My Woman contains 8 short stories written when she was in her 20s. They were titled as "In Some Day"," Child Buddha", "What is the Emotion of the Dog in the Evening", "Amidst Red 
Flowers", "The Fruit of my Woman", "Nine Chapters", "White Flowers Floating” and “The River Running with the Railway". All these short stories share the theme of rejecting human brutality and violence.

The title story, "The Fruit of my Woman" digs into hurt, desire and relief from suffering. It is a daringly eccentric story about how a woman becomes a plant. Kang chooses nature as the main theme and sets plant as the stereotype in most of her works. She was always curious about humanity. In The Vegetarian as well as “The Fruit of my Woman” Kang explores the question of being human. Her works are protests against human violence. She had bitter experiences during the Gwangju Massacre and this motivated her to bring up works that reject human brutality. The Gwangju Massacre in May 1980 and the February 2009 incident in Youngsan where humans commit violence against other humans haunted Kang for so long.

Ecofeminism finds itself as a movement that bridges the gap between feminism and ecology and which transforms both to create an integrated praxis to end all forms of domination. Ecofeminists recognize that women and nature are interconnected, and they choose to embrace this connection as a source of emancipation and as the basis for the demurral of the patriarchal suppression of women and nature. Both women and non human nature are being considered as other. Ecofeminists argue that women are better than men to relate with nature and they are in fact closer to nature. Women, through their quirky bodily alteration like ovulation, menstruation, pregnancy, birthing and breastfeeding are closer to and can connect with Mother Earth. Women's oppressed state of being harassed by men ends up in developing a special insight and connection with nature. Ecofeminists derive morality based on trivializing feminine values of care, trust, love and friendship that is used to overcome all forms of ascendancy.

Han Kang's exasperating novel, The Vegetarian, clearly exhibits that women are biologically closer to nature. Kang wrote this novel as an objection against human violence and male dominance. According to her husband, taciturn housewife Yeong-hye is 'completely unremarkable in every way' (Kang, 2015) until she woke up one morning from a nightmare and decided not to eat meat anymore. The story is about her metamorphosis to something more petrifying.

Complete powerlessness is a myth. Histories prove that people thought to be naturally 'malleable' have broken chains and chosen to stand up for themselves. They have become assertive and dominant forces. It can be said that within each submissive soul lies a dominant nature. In a country like South Korea, turning vegan without a reason is unthinkable. Yeong-hye, a quiet, small and unobtrusive lady breaks all norms to escape the constraints of the environment. She believes that being human is just a myth that doesn't exist. Her husband and family are not happy about her making the choice of becoming a vegetarian. They are frustrated and angry with her because she isn't ready to explain to them why she has done this and when anyone asks her about her horrible transformation, the only response is 'I had a dream' (Kang, 2015). She then starts exhibiting a lot of strange behaviour and she becomes a danger to herself.

An incident in the novel shows the domination of men in Yeong-hye's life and her clear rejection against the whole patriarchy. Yeong-hye's family arrives at her home to check with her dreadful metamorphosis. They have meals together and everybody asks her to eat meat. She refuses. Fed up with all the drama going on, her violent father himself forces her, 'Enough! You, Yeong-hye! After all I told you, your own father! Do you truly intend to go on like this? Human beings need certain nutrients... if you intend to follow a vegetarian diet you should sit down and draw a proper, wellbalanced meal plan. Just look at your face!' (Kang, 2015). Dishes of stir-fried beef, sweet and sour pork, steamed chicken and octopus noodles were arranged on the dining table. Her father asks Yeong-hye to eat any meat dish that she likes. Her father boomed 'Well, what are you waiting for? Come on, eat up' (Kang, 2015). Yeong-hye stayed silent. They all 


\section{Han Kang's the Vegetarian and the Fruit of My Woman}

continuously compelled her to take meat. After long silence, Yeong-hye spoke up: 'I won't eat it' (Kang, 2015). Her speech was clear and distinct. This voice is a rebellion against male supremacy. Her father was not ready to leave it right away. He yelled at Yeong-hye, 'My heart will pack in if this goes on any longer! ... Don't you understand what your father's telling you? If he tells you to eat, you eat!' (Kang, 2015). Yeong-hye again responded to this, not the least bit apologetic, 'I do not eat meat' (Kang, 2015). Her father took up a pair of chopsticks, picked up a piece of pork and stood in front of Yeong-hye. He stooped and shoved the pork at her face. Yeong-hye pushed away the chopsticks showing her grudge and said, 'Father, I don't eat meat' (Kang, 2015). In an instant her father's flat palm fell on her cheek. Her father called for Mr. Cheong, Yeong-hye's husband and her brother, Yeong-ho and asked them to hold both her hands. Mr. Cheong, who witnessed the incident says, 'I approached my wife hesitantly. He'd hit her so hard that blood showed through the skin of her cheek. Her breathing was ragged, and it seemed that her composure had finally been shattered' (Kang, 2015). All men present there join hands to cruelly harass the innocent girl. Her sister, In-hye was the only one who stood by her side while all this happened. Mr. Cheong remembers the whole horrible incident in the first part of the novel. He talks about the brutality of Yeong-hye's father and brother,

Having thrown down the chopsticks, he now picked up a piece of pork with his fingers and approached my wife. She was hesitantly backing away when her brother seized her and sat her down. A moaning sound came from her tightly closed mouth. She was unable to say a single word in case, when she opened her mouth to speak, the meat found its way in (Kang, 2015).

In-hye held her father by the waist to help her helpless sister. But he wasn't ready to give up. He split her lips with his strong fingers and crushed the pork on Yeong-hye's lips. She struggled with agony. He slapped her even harder that the force of the slap knocked her mouth open and he jammed the pork in it. As soon as her father released her, Yeong-hye growled and spat out the meat. An animal cry of anguish burst from her lips, '...get away!' (Kang, 2015). She turned back and picked up the fruit knife. She intensely stared at them and brandished the knife, 'Blood ribboned out of her wrist. The shock of red splashed over white china. As her knees buckled and she crumpled to the floor...' (Kang, 2015).

The patriarchy is literal in this scene. This act of Yeong-hye represents the outburst of women towards the violent social norms. Social convention is very important to the family, and Yeong-hye is defying it. They read her apathy and passivity as insolence. The most passive resistance can provoke the most enormous tantrum.

The other two men in Yeong-hye's life, her husband and brother-in-law have tried to exploit her. The two men have very little sympathy for each other, but they are allied in feeling a violent desire for Yeong-hye, and in taking advantage of her tameness. Neither of them truly sees Yeong-hye as a person, instead she is seen as an object, a decoration or a property.

The third part of the novel, The Vegetarian is narrated by In-hye, Yeong-hye's sister. She describes how Yeonghye's vegetarianism grows to severe levels of insanity. She starts refraining from many social norms, including the daily intake of food, sex and other worldly activities. Yeong-hye is admitted to a mental hospital, where, despite receiving highlevel treatment for craze, she sticks to the belief that being a plant is the best way to avoid human violence by no longer being a human and avoid causing it by no longer having to consume meat. At the end, Yeong-hye happily declares herself to be no longer an animal.

In "The Fruit of my Woman" the unnamed wife gets transformed into a plant. She literally becomes a plant. Her 
nameless husband describes the change in her body, 'A thick white spray of roots sprouted out of her inner thighs. Dark red flowers blossomed from her chest. Twin stamens, white at the ends, yellowish and thick at the roots, pierced out through her nipples' (Kang, 2016). When seasons change, her body changes as well, 'As autumn deepened, I witnessed a clear orange light gradually imbue my wife's body. When I opened the window, her up stretched arms would sway ever so slightly, moving with the wind currents' (Kang, 2016). 'As autumn drew to a close, her leaves began to fall in twos and threes. Her body slowly changed from its former orange to an opaque brown' (Kang, 2016).

Han Kang wrote "The Fruit of My Woman", and it is in many ways a direct precursor to her 2015 novel, The Vegetarian. In both, a married couple in their early thirties finds their thus far uneventful lives turned upside down when the woman starts to undergo a transformation. But while The Vegetarian shuns anything explicitly supernatural - Yeonghye's desire to turn into a tree is seen by those around her as a symptom of mental illness, the nameless protagonist of "The Fruit of My Woman" really does become a plant, leaves and berries.

Yeong-hye and the unnamed wife oppose human brutality and no longer want to remain human beings. Yeonghye says that she is not an animal anymore. Both women characters transform themselves into plants to show their strong disagreement to human violence and patriarchal norms. They represent all women as well as the Mother Earth who are being dominated by men. Their act of embracing nature shows their clear refusal of the existing conventions set by the so called 'patriarchy'.

\section{CONCLUSIONS}

In conclusion, Han Kang's The Vegetarian and "The Fruit of my Woman" can be given an important place in the history of ecofeminism, because it carries various ecofeminist aspects. In The Vegetarian, firstly ecofeminist aspects are shown through the protagonist's relationships with the male characters in her life. Then in Yeong-hye and Mr. Cheong's marriage, man's superior power over women and women's loss of identity and suppressed state are clearly illustrated. Secondly, Yeong-hye's story is the alienation from the patriarchal world until she finds a world of her own in nature. She not only lacks all social contacts, but also feels isolated from her family. She reacts against the patriarchy. Her strong disapproval can be seen in the scene where her father forces her to eat meat and she firmly rejects him. She stands up against human brutality and in turn transforms herself into a plant. She believes that she no longer is an animal. However, Yeong-hye's journey turns out to be a spiritual journey for her in which she realizes that she belongs to nature. In fact, she becomes nature.

As for "The Fruit of my Woman", Han Kang doesn't talk much about the domination of men and the oppression of women. She mostly talks about the relationship between women and nature. The incidents in the story show that women are closer to nature than men. The nameless lady literally becomes a plant. Leaves, branches, and even berries grow on her body. Both women characters in the works of Han Kang discover their connection to the Universe, which is one of the main interests of ecofeminist theory. Despite the fact that The Vegetarian and "The Fruit of my Woman" have different attitudes to ecofeminism and its main concerns, the fact that they investigate the relationships between women and nature makes feasible for ecofeminist criticism.

\section{REFERENCES}

1. Bartky, S. L. (1990). Femininity and Domination: Studies in the Phenomenology of Oppression. Routledge.

2. Griffin, Susan. (1978). Woman and the Nature: The Roaring Inside Her. New York: Harper and Row Publishers. 
The Flowering of Human Consciousness: An Ecofeminist Reading of

Han Kang's the Vegetarian and the Fruit of My Woman

3. Kang, Han. (2016). “The Fruit of My Woman”. Granta Magazine, vol. 133. Retrieved from https://granta.com/the-fruit-of my-woman/.

4. Kang, Han. (2015). The Vegetarian. Translated by Deborah Smith, London, UK: Portobello Books.

5. Mellor, Mary. (1998). Feminism and Ecology: An Introduction. New York UP.

6. Mukhopadhyay, Arpita. (2016). Feminisms. Hydrabad, India: Orient Black Swan Private Limited.

7. Ruether, Radford Rosemary. (1975). New Woman, New Earth: Sexist Ideologies and Human Liberation. Delhi, India: Harper Collins Publishers. 
